\title{
Prediction of thrust forces and hole diameters using artificial neural networks in drilling of AISI D2 tool steel with cemented carbide tools
}

\author{
${ }^{1}$ Sıtkı Akıncıoğlu, ${ }^{* 2}$ Faruk Mendi, ${ }^{* 3}$ Adem Çiçek, ${ }^{1}$ Gülşah Akıncıoğlu \\ ${ }^{1}$ Gümüşova Vocational School of Higher Education Düzce University, TURKEY \\ ${ }^{* 2}$ Faculty of Technology, Department of Manufacturing Engineering, Gazi University, TURKEY \\ ${ }^{* 3}$ Faculty of Engineering and Natural Sciences, Department of Mechanical Engineering, \\ Yıldırım Beyazıt University, TURKEY
}

*Corresponding author: Sttkı AKINCIOĞLU Address: Gümüşova Vocational School of Higher Education, Düzce University, 81850, Düzce TURKEY. E-mail address: sitkiakincioglu@gmail.com, Phone: +905054606475 Fax: $+903807313124$

\begin{abstract}
In this study, the effects of cutting speed, feed rate and different types of coating materials on thrust force and hole diameter were investigated in drilling of AISI D2 cold work tool steel. In addition, the thrust forces and hole diameters were predicted by artificial neural networks (ANN) using experimental data. Uncoated, TiN, TiAlN monolayer and TiAlN/TiN multi-layer coated cemented carbide drills with diameter of $5 \mathrm{~mm}$ were used in drilling experiments. The holes were drilled at different combinations of four cutting speeds $(50,55,60,65 \mathrm{~m} / \mathrm{min})$, two feed rates $(0.063$ and 0.08 $\mathrm{mm} / \mathrm{rev})$, and fixed depth of cut $(7 \mathrm{~mm})$. Experimental results showed that the lowest thrust forces and hole diameters were obtained with TiAlN/TiN multi-layer coated drills. After ANN training, it was found that the $\mathrm{R}^{2}$ values are very close to 1 for both training and test sets. RMSE values are smaller than 0.03 , and mean error values are smaller than $5 \%$ for the test set. This case shows that ANN is a powerful method for prediction of thrust forces and hole diameters.
\end{abstract}

Key words: Coatings, Thrust force, Hole diameter, Artificial neural network

\section{Introduction}

Cutting force is one of the most critical outputs in cutting process. Cutting forces affects many results such as power consumption, surface roughness, roundness error and hole diameter [1]. Therefore, it is very important to specify ideal cutting parameters in measurement of lower cutting forces [2, 3]. Through improvements in coating technology, high speeds are reached in metal cutting process. In addition, tool coatings provide longer tool life, better surface finish and lower cutting forces. For example, due to TiN coatings with high hardness, the tool has a good crater wear resistance and low coefficient of friction [4-6]. In addition to the high hardness, TiAlN coatings have chemical stability, longer tool life and excellent machining performance. $[7,8]$. The TiAlN coatings have also shown some interesting properties such as high fracture toughness, corrosion and wear resistance [9]. Also, the multilayer coatings were developed to provide higher wear resistance and hot hardness and lower chemical affinity with any work piece material [10]. It was reported that multi-layer TiN/TiAlN coatings had lower wear rate than monolayer TiAlN [11]. 
ANN is an algorithm developed to predict new data by means of learning from some series of experimental data without external help $[12,13]$. In recent years, ANN is frequently used the industrial field. [14, 15]. Aykut et al. [16] used ANN for modeling the effects of machinability on cutting parameters for face milling of stellite 6 in asymmetric milling processes. Results showed that the ANN can be effectively used for predicting the effects of machinability on cutting parameters. Benardos et al. [17] presented a neural network modeling approach for the prediction of surface roughness in CNC face milling. ANN predicted the surface roughness with a mean squared error equal to $1.86 \%$. Mounayri et al. presented an integrated product development system for optimized CNC ball end milling. First, the developed model was extended from flat-end milling to ball-end milling. Second, the optimization was extended from 2D (speed and feed) to $3(1 / 2) \mathrm{D}$ (speed, feed, radial and axial depths of cut). Third, the modeling and simulation of the flat-end milling was extended to include more input variables. Finally, a new, more efficient and practical, neural network technique was introduced to replace the backpropagation neural network, and was successfully implemented for the case of ball-end milling. A very good match between predicted and experimentally measured process parameters was found [18].

The objectives of this study are to investigate the effects of cutting parameters on the thrust force and hole diameter, and to reduce number of complex and time-consuming experimental studies using ANN predictions.

\section{Materials and Method}

During experiments, AISI D2 cold work tool steel was used as workpiece material. In order to perform

dynamometer (Figure 2) was rigidly mounted to table of $\mathrm{CNC}$ vertical machining center. thrust force measurements, Kistler 9257B model

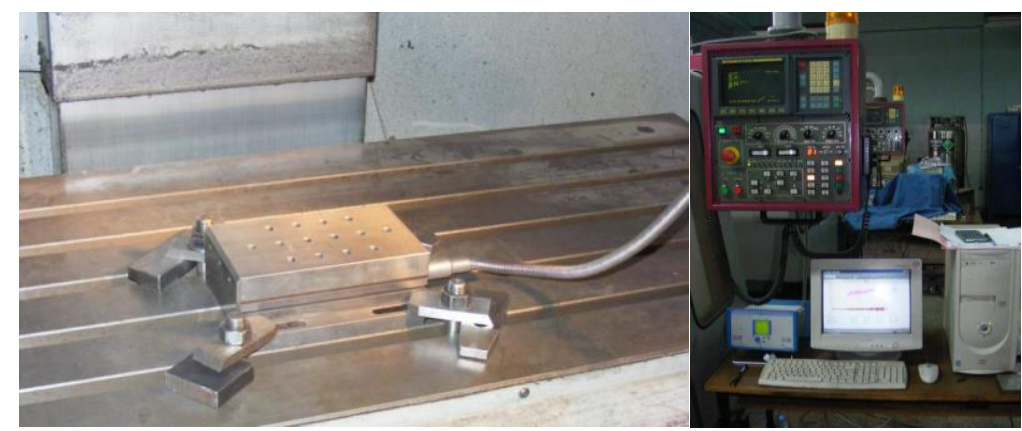

Figure 2.Kistler 9257B trademark dynamometer

In order to fix workpiece to dynamometer, the specimens were cut with $170 \times 100 \times 12 \mathrm{~mm}$ dimensions, and two holes with $125 \mathrm{~mm}$ distance and $13 \mathrm{~mm}$ diameter were drilled. Considering the hardness distribution around drilled hole, the distance between holes was carefully designed to be equal. So it was aimed to distribute the heat as equally as possible. The diameters of drills (d) were determined as $5 \mathrm{~mm}$. In order to achieve ideal results at the end of drilling process, the length of hole was determined as $7 \mathrm{~mm}$ which is less than $15 \mathrm{~mm}(\mathrm{~d} \mathrm{x} \mathrm{3})[19,20]$. The chemical composition of AISI D2 cold work tool steel is given in Table 1 .

Table 1. The chemical composition of AISI D2 cold work tool steel

\begin{tabular}{lllllll}
\hline $\mathbf{C} \%$ & $\mathbf{S i} \%$ & Mn\% & Cr\% & Ni\% & Mo\% & V\% \\
\hline 1.003 & 0.134 & 0.271 & 11.88 & 0.193 & 0.693 & 0.713 \\
\hline During the experiments, 4 different sets of drills & & belonging to Guhring Company (uncoated, PVD-TiN,
\end{tabular}


PVD-TiAlN monolayer, and PVD-TiAlN/TiN multilayer coated). The dimensions of drills used in

experiments are given in Figure 1 and Table 2.

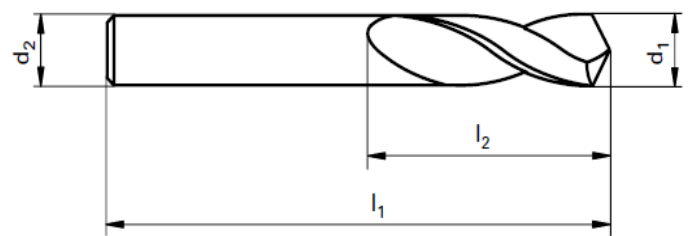

Figure 1. Drill dimensions

The properties of sets with same dimensions are in Table 2.

Table 2. Tool properties

\begin{tabular}{ll}
\hline & Properties \\
\hline Tool type & Twist drill \\
Standard & DIN 6539 \\
Coatings & Uncoated, TiN, TiAlN, TiAlN/TiN \\
Diameter $\left(\mathrm{d}_{1}, \mathrm{~d}_{2}\right)$ & $5 \mathrm{~mm}$ \\
Tip angle & $135^{\circ}$ \\
Helix angle & $35^{\circ}$ \\
Helix length $\left(\mathrm{l}_{2}\right)$ & $26 \mathrm{~mm}$ \\
Length $\left(\mathrm{l}_{1}\right)$ & $62 \mathrm{~mm}$ \\
\hline
\end{tabular}

Additional to set properties, the properties of different coating materials are in Table 3 with details.

Table 3. Coating properties of the coated drills.

\begin{tabular}{llll}
\hline & TiN-PVD & TiAlN-PVD & TiAlN/TiN -PVD \\
\hline Tool material & Cemented carbide & Cemented carbide & Cemented carbide \\
Tool diameter $(\mathrm{mm})$ & 5 & 5 & 5 \\
Coating thickness $(\mu \mathrm{m})$ & 2.5 & 2.5 & 4 \\
Hardness (HV 0.05) & 2200 & 3300 & 3600 \\
Coating type & Monolayer & Monolayer & Multi-layer \\
Number of layers & 1 & 1 & 6 \\
Friction coefficient & 0.25 & 0.3 & 0.3 \\
\hline
\end{tabular}

The experimental studies were performed in Johnford VMC-550 trademark CNC vertical machining center. The measurement of diameter of holes was performed with Mitutoyo trademark CRT-A C544 model 3D CMM (Coordinate Measuring Machine). Cutting speed and feed rate were determined after preliminary drilling experiments and examination of the catalogue of Guhring Company. During the experiments; 4 different drills, 4 different cutting speeds $(50,55,60$, $65 \mathrm{~m} / \mathrm{min}), 2$ different feed rates $(0.08 \mathrm{~mm} / \mathrm{rev}$ for $0.063)$, and constant depth of cut $(7 \mathrm{~mm})$ were used, totally 32 experiments were performed.

\subsection{Artificial neural network}

ANN consists of artificial neurons. ANN has three main layers (input, hidden and output layers) [21]. Neurons in input layer transfer data from external world to hidden layer. In hidden layer, outputs are produced by using data from neurons in input layer, bias, and summation and activation functions. In the output layer, the output of network is produced by processing data from hidden layer and sent to external world. The summation function calculates net input coming to a cell. The most common function is to calculate the weighted sum. Inputs are the knowledge from other cells or external world to the input cells. Weights $\left(\mathrm{w}_{1}, \mathrm{w}_{2} \quad \ldots \mathrm{w}_{\mathrm{n}}\right)$ are the values which determine the effect of input set or another processing element in previous layer on the processing element. Each input value is multiplied by weight value which connects it to the processing element, and then it is 
combined by summation function. Thus, net input of the network can be found. Activation function provides a curvilinear match between input and output layers. In addition, it determines the output of the cell by processing net input to the cell. Selection of appropriate activation function significantly affects network performance. Recently, logistic sigmoid transfer function has been commonly used as an activation function in multilayer perceptron model. For this reason, the logistic sigmoid transfer function was used in this study. There are many learning algorithms in order to determine weights in artificial neutral network. One of the most common learning algorithms is back propagation. The back propagation method updates the weights in accordance with difference between available data and network output.
Learning parameter used in the method has a great importance in order to reach the optimal results. Learning parameter can be constant or dynamically updated in the model. There are various training functions such as Bayesian regularization, gradient descent with adaptive learning rule, gradient descent with momentum and adaptive learning rule, scaled conjugate gradient and Levenberg-Marquardt. In order to acquire the closest output values to experimental results, the best learning algorithm and optimum number of neurons in hidden layer was determined. For this reason, both SCG and LM learning algorithms and different numbers (3-10) of neurons in hidden layer were used in the built network structure for thrust force [22].

Table 4. Statistical data for the thrust force

\begin{tabular}{cccccccc}
\hline \multirow{2}{*}{$\begin{array}{c}\text { Learning } \\
\text { algorithm }\end{array}$} & Network & \multicolumn{3}{c}{ THRUST FORCE } \\
\cline { 2 - 7 } & structure & \multicolumn{3}{c}{ Training data } & \multicolumn{3}{c}{ Test data } \\
\cline { 2 - 7 } & & $\mathbf{R}^{\mathbf{2}}$ & RMSE & MEP & $\mathbf{R}^{\mathbf{2}}$ & RMSE & MEP \\
\hline \multirow{4}{*}{ SCG } & $3-3-1$ & 0.018629 & 0.998214 & 6.454113 & 0.032572 & 0.993781 & 7.584499 \\
& $3-4-1$ & 0.006953 & 0.999752 & 2.217500 & 0.024632 & 0.996319 & 8.218417 \\
& $3-5-1$ & 0.009279 & 0.999558 & 2.605711 & 0.026415 & 0.995239 & 11.449130 \\
& $3-6-1$ & 0.006191 & 0.999803 & 2.150960 & 0.020266 & 0.997291 & 9.010987 \\
& $3-7-1$ & 0.006200 & 0.999803 & 1.917535 & 0.012098 & 0.999053 & 6.129984 \\
& $3-8-1$ & 0.006173 & 0.999805 & 2.061780 & 0.025690 & 0.995700 & 12.296259 \\
& $3-9-1$ & 0.006131 & 0.999807 & 2.037776 & 0.038658 & 0.990367 & 15.969927 \\
& $3-10-1$ & 0.006004 & 0.999815 & 1.981031 & 0.026479 & 0.995166 & 11.053018 \\
\hline \multirow{4}{*}{ LM } & $3-3-1$ & 0.015192 & 0.998814 & 4.865211 & 0.029990 & 0.994247 & 10.803812 \\
& $3-4-1$ & 0.005517 & 0.999843 & 1.667968 & 0.028017 & 0.995080 & 10.860849 \\
& $3-5-1$ & 0.006091 & 0.999809 & 2.045453 & 0.017124 & 0.998177 & 5.767293 \\
& $3-6-1$ & 0.006107 & 0.999809 & 2.165246 & 0.016875 & 0.998160 & 6.068789 \\
& $3-7-1$ & $\mathbf{0 . 0 0 5 7 5 8}$ & $\mathbf{0 . 9 9 9 8 3 0}$ & $\mathbf{1 . 7 8 2 2 0 5}$ & $\mathbf{0 . 0 0 9 4 5 4}$ & $\mathbf{0 . 9 9 9 4 0 8}$ & $\mathbf{4 . 6 8 6 0 1 4}$ \\
& $3-8-1$ & 0.005768 & 0.999831 & 1.645321 & 0.021584 & 0.997086 & 10.074594 \\
& $3-9-1$ & 0.005818 & 0.999826 & 1.782259 & 0.022330 & 0.996934 & 10.294473 \\
& $3-10-1$ & 0.005137 & 0.999865 & 1.164660 & 0.029407 & 0.994842 & 12.308946 \\
\hline
\end{tabular}

In consequence of trials, the best learning algorithm and network architecture for prediction of thrust force became LM: 3-7-1. Determination of the best learning algorithm and optimal number of neurons for the thrust force is demonstrated in Table 4 . The best learning algorithms and ANN architecture for the hole diameter are given as LM: 3-5-1, respectively. Determination of percentages of training and test data has an important role for building of ANN architecture. 32 experimental results were prepared for training and test data of ANN. In this context, 6 data for test and 26 data for training were randomly selected. The digits for the cutting tool to be entered into the ANN were denoted as $\mathrm{TiN}=1 \mathrm{TiAlN},=2$, TiAlN/TiN $=3$ and uncoated $=4$ because they do not have numerical values [23]. All the values measured in the experiments are given in Table 5. 
Table 5. All experimental data

\begin{tabular}{|c|c|c|c|c|c|}
\hline $\begin{array}{c}\text { Experiment } \\
\text { no }\end{array}$ & $\begin{array}{l}\text { Coating } \\
\text { material }\end{array}$ & $\begin{array}{c}\text { Cutting } \\
\text { speed } \\
(\mathbf{m} / \mathbf{m i n})\end{array}$ & $\begin{array}{c}\text { Feed } \\
\text { rate } \\
(\mathrm{mm} / \mathrm{rev})\end{array}$ & $\begin{array}{c}\text { Thrust } \\
\text { force } \\
\text { (N) }\end{array}$ & $\begin{array}{c}\text { Hole } \\
\text { diameter } \\
(\mathbf{m m})\end{array}$ \\
\hline 1 & $\overline{\mathrm{TiN}}$ & 50 & 0.063 & 575 & 5.0039 \\
\hline 2 & TiN & 55 & 0.063 & 570 & 5.0029 \\
\hline 3 & TiN & 60 & 0.063 & 568 & 5.0016 \\
\hline 4 & TiN & 65 & 0.063 & 576 & 5.0024 \\
\hline 5 & TiN & 50 & 0.08 & 694 & 5.0049 \\
\hline 6 & TiN & 55 & 0.08 & 674 & 5,0035 \\
\hline 7 & TiN & 60 & 0.08 & 668 & 5.0022 \\
\hline 8 & TiN & 65 & 0.08 & 669 & 5.0030 \\
\hline 9 & TiAlN & 50 & 0.063 & 585 & 5.0045 \\
\hline 10 & TiAlN & 55 & 0.063 & 581 & 5.0034 \\
\hline 11 & TiAlN & 60 & 0.063 & 578 & 5.0025 \\
\hline 12 & TiAlN & 65 & 0.063 & 590 & 5.0033 \\
\hline 13 & TiAlN & 50 & 0.08 & 705 & 5.0052 \\
\hline 14 & TiAlN & 55 & 0.08 & 685 & 5.0044 \\
\hline 15 & TiAlN & 60 & 0.08 & 680 & 5.0032 \\
\hline 16 & TiAlN & 65 & 0.08 & 690 & 5.0037 \\
\hline 17 & TiAlN/TiN & 50 & 0.063 & 573 & 5.0026 \\
\hline 18 & TiAlN/TiN & 55 & 0.063 & 565 & 5.0016 \\
\hline 19 & TiAlN/TiN & 60 & 0.063 & 554 & 5.0009 \\
\hline 20 & TiAlN/TiN & 65 & 0.063 & 568 & 5.0013 \\
\hline 21 & TiAlN/TiN & 50 & 0.08 & 686 & 5.0041 \\
\hline 22 & TiAlN/TiN & 55 & 0.08 & 671 & 5.0025 \\
\hline 23 & TiAlN/TiN & 60 & 0.08 & 665 & 5.0018 \\
\hline 24 & TiAlN/TiN & 65 & 0.08 & 669 & 5.0023 \\
\hline 25 & Uncoated & 50 & 0.063 & 771 & 5.0044 \\
\hline 26 & Uncoated & 55 & 0.063 & 755 & 5.0035 \\
\hline 27 & Uncoated & 60 & 0.063 & 747 & 5.0024 \\
\hline 28 & Uncoated & 65 & 0.063 & 731 & 5.0023 \\
\hline 29 & Uncoated & 50 & 0.08 & 900 & 5.0062 \\
\hline 30 & Uncoated & 55 & 0.08 & 875 & 5.0052 \\
\hline 31 & Uncoated & 60 & 0.08 & 850 & 5.0042 \\
\hline 32 & Uncoated & 65 & 0.08 & 820 & 5.0041 \\
\hline
\end{tabular}

In back propagation model, scaling of inputs and outputs dramatically affects performance of artificial neural network. As mentioned above, logistic sigmoid transfer function was used in this study. One of the characteristics of this function is that only a value between 0 and 0.9 can be produced. In this study, the input and output values were normalized between 0 and 0.9 using formula in Eq. 4 .

$n d_{i}=0.8 \times\left(\frac{\mathrm{d}_{\text {min }}-\mathrm{d}_{\mathrm{i}}}{d_{\text {min }}-d_{\text {max }}}\right)+0.1$
Where, $d_{i}$ and $n d_{i}$ are $i_{t h}$ data and $i_{t h}$ normalized data, respectively; $d_{\min }$ and $d_{\max }$ are minimum and maximum data in whole data, respectively. To understand whether an ANN is making good predictions or not, the test data that has never been presented to the network is used, and the results are checked at this stage. RMSE (root mean square error), $\mathrm{R}^{2}$ (determination coefficient) and MEP (mean error percentage) values have been used for comparisons [13]. 


\section{Experimental results and discussion}

\subsection{Cutting Forces}

While the measured thrust force values were evaluated in drilling the AISI D2 cold work tool steel (Figure 3), the lowest thrust force values were obtained with TiAlN/TiN multilayer coated drills in all measurements due to their higher wear resistance. For all cutting conditions, it was found that thrust forces were always higher in uncoated drills than those in coated drills. The thrust forces obtained in TiN coated drills were better than those obtained in TiAlN coated drills. It is thought that thrust forces were found low as a result of low friction coefficients of TiN coatings $[2,4,5]$. The lowest value measured with a TiAlN/TiN coated drill is $554 \mathrm{~N}$ at feed rate of $0.063 \mathrm{~mm} / \mathrm{rev}$ and cutting speed of $60 \mathrm{~m} / \mathrm{min}$. When evaluating the thrust forces according to feed rates (Figure 3), thrust force values remarkably increased with increasing feed rate. It can be thought that increasing chip section as a result of increasing feed rates affected thrust forces negatively. Although there are many effects affecting thrust forces, cutting speed and feed rate affect at most $[24,25]$. Considering the thrust force, $0.063 \mathrm{~mm} / \mathrm{rev}$ is the ideal feed rate.
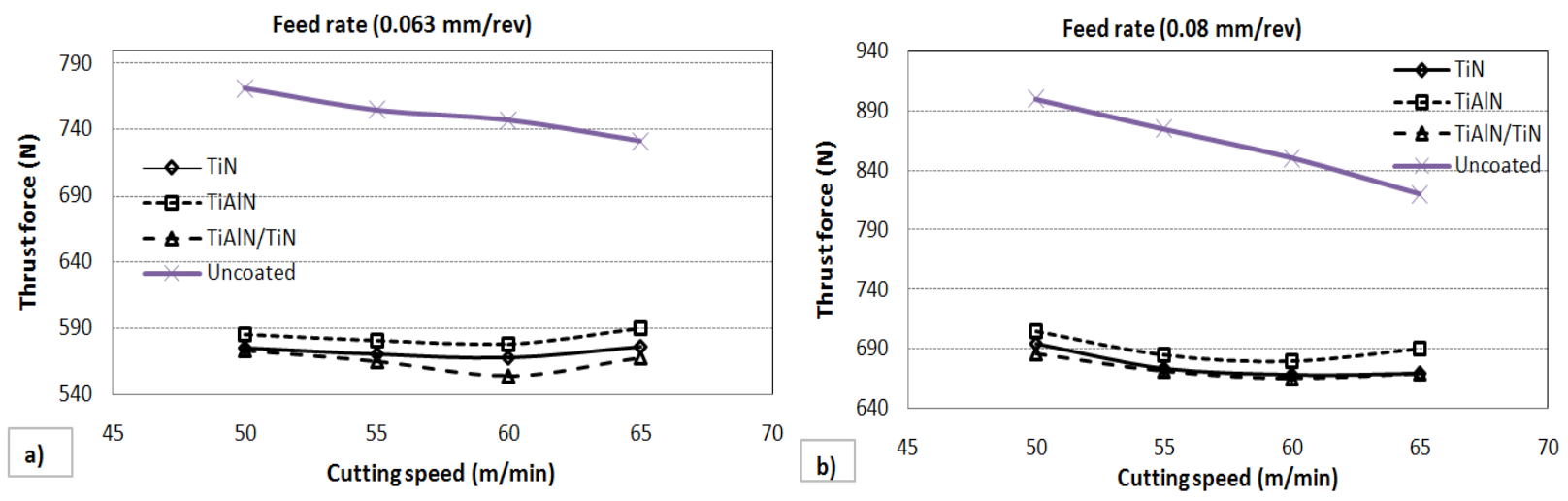

Figure 3. Thrust forces according to cutting speeds and drill types, a) $0.063 \mathrm{~mm} / \mathrm{rev}$ b) $0.08 \mathrm{~mm} / \mathrm{rev}$.

The decrease of cutting speed increases the amount of temperature transferred to work piece, so it increase the temperatures in cutting zone [2]. The thrust forces slightly decreased until cutting speed of $60 \mathrm{~m} / \mathrm{min}$ because plastic deformation facilitated with increasing temperatures in cutting zone. In addition, certain high levels of cutting speed are important lifetime of the drills [24-26]. At especially cutting speed of $65 \mathrm{~m} / \mathrm{min}$, the thrust forces increased owing to rapid tool wear. The best result was obtained at cutting speed of $60 \mathrm{~m} / \mathrm{min}$.

\subsection{Hole diameters}

When analyzing the hole diameters measured at the end of experiments, it is seen that there is a relationship between hole diameters and thrust forces.
Higher cutting force leads to lower hole quality. When considering the values obtained in higher feed rates (Figure 4.), it is seen that increasing feed rates lead to increases in a hole diameter. In parallel with increasing cutting forces, hole diameter values also increased as a result of increasing feed rate. Higher feed rates lead to higher thrust forces. It can be said that the vibration as a result of increasing thrust forces may affect hole diameters negatively. The temperatures occurring as a result of increasing cutting speed lead to easy plastic deformation and removing of chips more fluently. So, the hole quality improves. It can be said that good hole diameter can be obtained with better chip removal. As a result of experiments, the hole quality was found better at cutting speed of $60 \mathrm{~m} / \mathrm{min}$. 

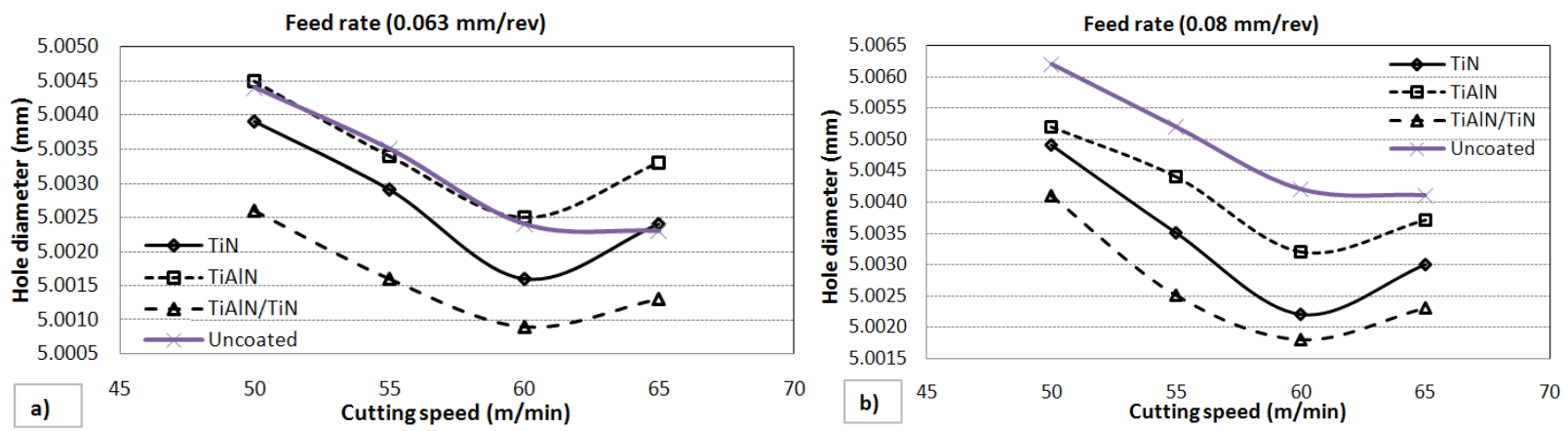

Figure 4. Holes diameters according to cutting speed and drill types, a) $0.063 \mathrm{~mm} / \mathrm{rev}$ b) $0.08 \mathrm{~mm} / \mathrm{rev}$.

When comparing the diameters of holes drilled using different drill types, the quality of holes drilled with multilayer coated drills was found as better due to their lower thrust forces. Also it was seen that the hole quality was worse in uncoated drills. The best hole diameter value (Ø5.0009 $\mathrm{mm}$ ) was obtained with TiAlN/TiN coated drill at cutting speed of $60 \mathrm{~m} / \mathrm{min}$ and feed rate of $0.063 \mathrm{~mm} / \mathrm{rev}$.

\subsection{Prediction of thrust force and hole diameter with ANN}

The aim of using the ANN model is to test the ability to the thrust force and hole diameter. In this study, a computer program was developed in MATLAB platform to predict the thrust force and hole diameter. The network has three input parameters. These are coating type $(\mathrm{Ct})$, cutting speed $(\mathrm{V})$ and feed rate $(\mathrm{f})$. Optimal statistical values obtained for each output parameter are given in Table 6. As shown in Table 6, it was shown that $\mathrm{R}^{2}$ are close to 1 for both training and test data. Similarly, RMSE and mean error percentage are fairly low. All MEP results for training and testing data are within acceptable error limits $( \pm 5 \%)$.

Table 6. Optimal results for thrust force and hole diameter

\begin{tabular}{ccccccccc}
\hline & & \multicolumn{4}{c}{ Training set } & \multicolumn{3}{c}{ Test set } \\
\hline Goal & Learning & Network & RMSE & $\mathbf{R}^{2}$ & MEP & RMSE & R $^{2}$ & MEP \\
\hline Ff & LM & $3-7-1$ & 0.005758 & 0.999830 & 1.782205 & 0.009454 & 0.999408 & 4.686014 \\
Dh & LM & $3-5-1$ & 0.011883 & 0.999455 & 2.808310 & 0.028303 & 0.994872 & 4.481558 \\
\hline
\end{tabular}

The equations of the thrust force and hole diameter are given in Eq. (2-3). Also, the thrust force and hole diameter can be accurately calculated by these formulas.

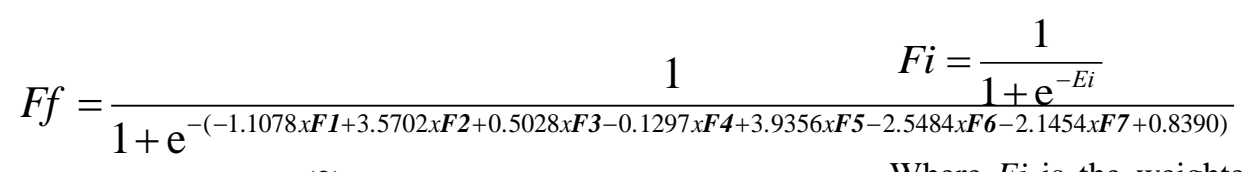

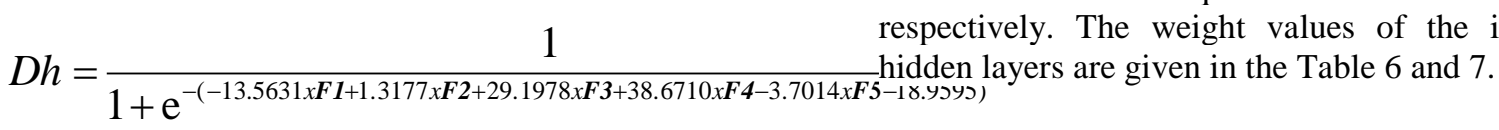


Table 7. The weights for the thrust force

\begin{tabular}{lllll}
\hline & \multicolumn{4}{l}{$E_{i}=w_{1} x C t+w_{2} x V+w_{3} x f+\theta i$} \\
\cline { 2 - 5 }$i$ & $w_{1}$ & $w_{2}$ & $w_{3}$ & $\theta_{i}$ \\
\hline 1 & -6.4684 & -2.7617 & -4.3080 & 16.4871 \\
2 & 10.6469 & -1.4917 & 3.8784 & -12.8674 \\
3 & -3.5996 & -7.1583 & 0.1896 & 2.3666 \\
4 & -7.4703 & -5.2997 & -4.5306 & 9.4656 \\
5 & 11.4510 & -0.4933 & -1.0716 & -8.9492 \\
6 & 7.0288 & -0.4474 & -3.4970 & -2.2664 \\
7 & -10.2174 & -0.7649 & -3.0773 & 2.1160 \\
\hline
\end{tabular}

Table 8. The weights for hole diameter

\begin{tabular}{lllll}
\hline & \multicolumn{4}{l}{$E_{i}=w_{1} x C t+w_{2} x V+w_{3} x f+\theta i$} \\
\cline { 2 - 5 }$i$ & $w_{1}$ & $w_{2}$ & $w_{3}$ & $\theta_{i}$ \\
\hline 1 & -2.1053 & -0.8394 & 1.6019 & 17.2975 \\
2 & 3.8276 & 51.1579 & 0.1055 & -36.6803 \\
3 & -5.2896 & 0.3984 & -0.7148 & 2.7084 \\
4 & 3.4728 & -0.5955 & 1.0886 & -1.9598 \\
5 & -7.5575 & 2.7807 & 11.3536 & -3.9671 \\
\hline
\end{tabular}

The comparisons of the thrust force and hole diameter values between the experimental values and ANN predictions are shown in Fig 6 and 7, respectively. As shown in these figures, the prediction capacities of the networks for the thrust force and hole diameter were fairly satisfactory.
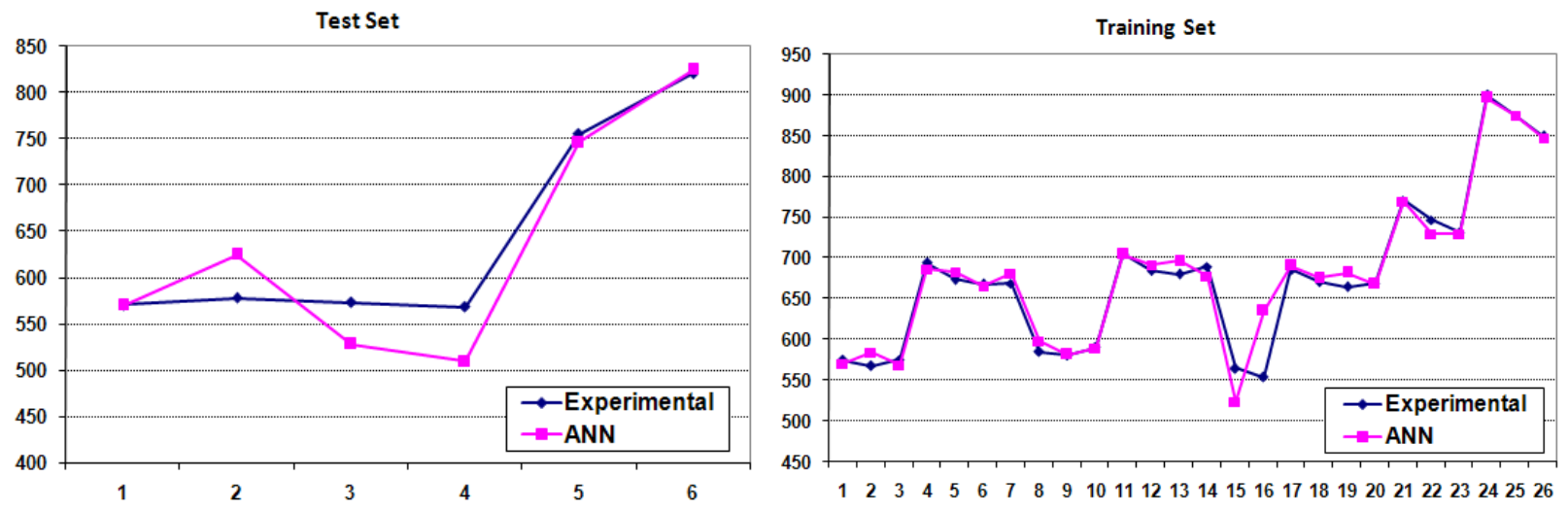

Figure 5. The performance of ANN for the thrust force 

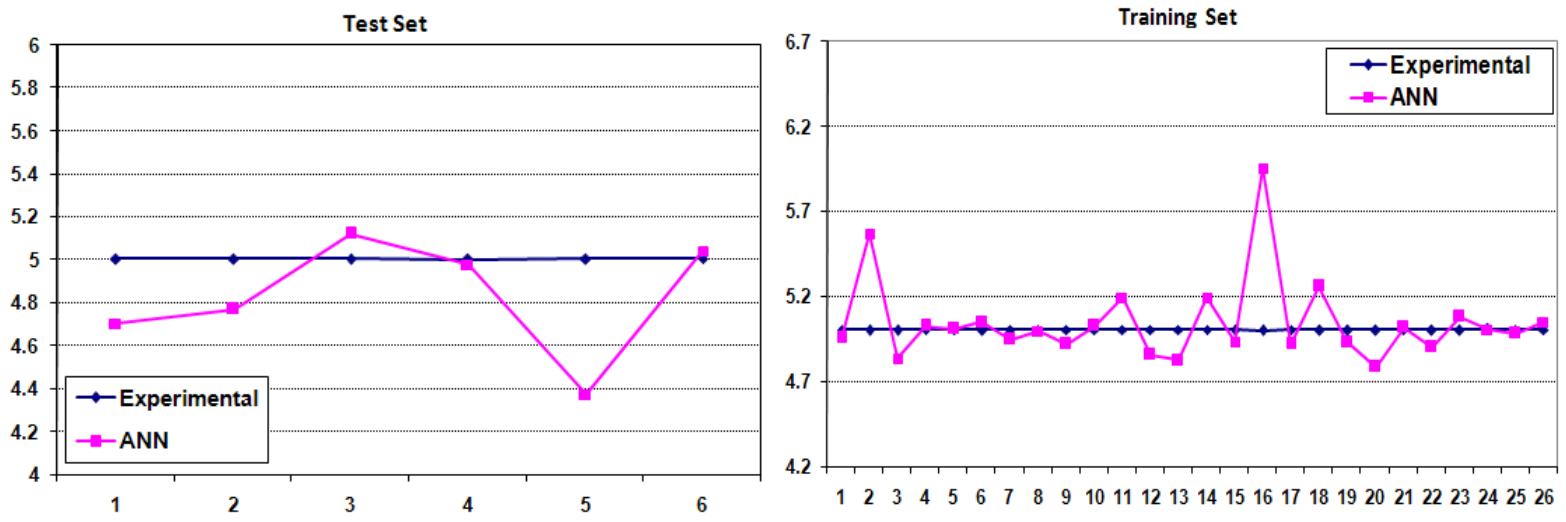

Figure 6. The performance of ANN for the hole diameter

\section{Results}

In this study, an ANN was used to predict the thrust force and hole diameter in drilling of AISI D2 cold work steel with uncoated, TiN, TiAlN monolayer and TiAlN/TiN multi-layer coated cemented carbide drills. The results can be drawn as follows:

- It was found that the lowest thrust force value was obtained with the TiAlN/TiN multi-layer coated drills due to its higher wear resistance. The optimal thrust force value was $554 \mathrm{~N}$ at the feed rate of $0.063 \mathrm{~mm} / \mathrm{rev}$ and the cutting speed of $60 \mathrm{~m} / \mathrm{min}$ in the conducted drilling experiments.

- The lowest value of hole diameter was also obtained with TiAlN/TiN multi-layer coated drills due to its lower thrust forces. The measured optimal hole diameter value was $\varnothing 5.0009 \mathrm{~mm}$ at a feed rate of $0.063 \mathrm{~mm} / \mathrm{rev}$ and cutting speed of $60 \mathrm{~m} / \mathrm{min}$.

- The optimal prediction results for the thrust force and hole diameter were obtained by network architectures of 3-7-1 and 3-5-1 with LM learning algorithms, respectively. In the ANN model, the determination coefficients for the thrust force and hole diameter were more than 0.99. MEP values for them values were within acceptable limits $( \pm 5 \%)$. The ANN results for both the thrust force and hole diameter were very satisfactory.

The prediction results showed that ANN is notably powerful in prediction of thrust force and hole diameter. So, the use of ANN is highly recommended in prediction of them instead of the experimental set ups to measure thrust force and hole diameter.

\section{References}

[1] Duran A, Acır A. HSS Torna Kalemindeki Talaş Açısının Kesme Kuvvetlerine Etkisi. Politeknik Dergisi 2004; 211-215.

[2] Çakır MC, Modern Talaşlı İmalat Yöntemleri. Vipaş A.Ş: Bursa;2000, 350-390.

[3] Basavarajappa S, Chandramohan G, Davim JP. Some studies on drilling of hybrid metal matrix composites based on Taguchi techniques. $\mathrm{j}$ mater process tech 2008; 196: 332-338

[4] Guu YH, Hocheng H. Improvement of fatigue life of electrical discharge machined AISI D2 tool steel by TiN coating. matscieng a-struct2001; 318: 155162.

[5] Lin TR. Cutting behavior of a TiN-coated carbide drill with curved cutting edges during the high-speed machining of stainless steel. $\mathrm{j}$ mater process tech 2002; 127: 8-16.

[6] Chou CWC, Liu XD. Study on the various coated twist drills for stainless steels drilling. $\mathrm{j}$ mater process tech 2000; 99: 226-230.

[7] Sharif S, Rahim EA. Performance of coated and uncoated-carbide tools when drilling titanium alloyTi-6Al4V. j mater process tech 2007;185: 72-76.

[8] Smith IJ, Gillibrand D, Brooks JS, Miinz D, Harvey S, Goodwin R. Dry cutting performance of 
HSS twist drills coated with improved TiAlN. surf coat tech 1997; 90: 164-171.

[9] Grips VKW, Barshilia HC, Selvi VE, Kalavati, Rajam KS. Electro chemical behavior of single layer CrN, TiN, TiAlN coatings and nano layered TiAlN/CrN multilayer coatings prepared by reactive direct current magnetron sputtering. Thin Solid Films 2006; 514: 204-211.

[10] Aihuaa L, Jianxina D, Haibinga C, Yangyanga C, Juna Z. Friction and wear properties of TiN, TiAlN, AlTiN and CrAlN PVD nitride coatings. int $j$ refract met h 2012; 31: 82-88.

[11] Hsieha JH, Liang C, Yu CH, Wu W. Deposition and characterization of TiAlN and multi-layered TiAlN/TiN coatings using unbalanced magnetron sputtering. surf coat tech 1998; 108-109 132-137.

[12] Zuperl U, Cus F. Optimization of cutting conditions during cutting by using neural networks. robotcim-int manuf2003; 19: 189-199.

[13] Çay Y, Çiçek A, Kara F, Sagiroglu S. Prediction of engine performance for an alternative fuel using artificial neural network. applthermeng2012; 37: 217 225.

[14] Sanjay C, Neema ML, Chin CW. Modeling of tool wear in drilling by statistical analysis and artificial neural network. j mater process tech 2005;170: 494-500.

[15] Wong SV, Hamouda AMS. Machinability data representation with artificial neural network. $\mathrm{j}$ mater process tech 2003; 138: 538-544.

[16] Aykut Ş, Gölcü M, Semiz S, Ergür HS. Modeling of cutting forces as function of cutting parameters for face milling of stellite 6 using an artificial neural network. J Mater Process Technol 2007; 190: 199-203.
[17] Benardos PG, Vosniakos GC. Prediction of surface roughness in CNC face milling using neural networks and Taguchi's design of experiments. robotcim-int manuf 2002; 18: 343-354.

[18] El-Mounayri H. Kishawy H. Briceno J. Optimization of CNC ball end milling: a neural network-based model. J mater process tech 2005; 166: 50-62.

[19] Michael F, Kahles JF, Koster WP. Surface finish and surface integrity. American Society for Metals1989; 3: 468-475.

[20] Kivak T. INCONEL 718'in Delinebilirliğinin Araştırılması. Yüksek Lisans Tezi, Gazi Üniversitesi Fen Bilimleri Enstitüsü Ankara 2007; 21-33.

[21] Çiçek A, Kıvak T, Samtaş G, Çay Y. Modelling of Thrust Forces in Drilling of AISI 316 Stainless Steel Using Artificial Neural Network and Multiple Regression Analysis. J mecheng2012; 587-8: 492498.

[22] Çay Y, Korkmaz İ, Çiçek A, Kara F. Prediction of engine performance and exhaust emissions for gasoline and methanol using artificial neural network. Energy 2013; 50: 177-186.

[23] Akıncıoğlu S, Mendi F, Çiçek A, Akıncıoğlu G. ANN-based prediction of surface and hole quality in drilling of AISI D2 cold work tool steel. Int J Adv Manuf Technol DOI 10.1007/s00170-012-4719-6.

[24] Davim JP, Baptista, A.M. Cutting force, tool wear and surface finishing drilling metal matrix composites. ProcInst Mech Eng 2001; 215: 177-183.

[25] Morin E, Masounave J, Laufer EE. Effect of wear on cutting forces in the drilling of metal matrix composites. Wear 1995; 184: 11-16.

[26] Songmene AV, Balazinzki M. Machinibility of graphitic metal matrix composites as a function of reinforcing particles. CIRP 1999; 48 (1): 77-80. 